\title{
The mechanism behind redox instability of anodes in high-temperature SOFCs
}

\author{
Klemensø, Trine; Chung, Charissa; Larsen, Peter Halvor; Mogensen, Mogens Bjerg
}

Published in:

Journal of The Electrochemical Society

Link to article, DOI:

$10.1149 / 1.2048228$

Publication date:

2005

Document Version

Publisher's PDF, also known as Version of record

Link back to DTU Orbit

Citation (APA):

Klemensø, T., Chung, C., Larsen, P. H., \& Mogensen, M. B. (2005). The mechanism behind redox instability of anodes in high-temperature SOFCs. Journal of The Electrochemical Society, 152(11), A2186-A2192.

https://doi.org/10.1149/1.2048228

\section{General rights}

Copyright and moral rights for the publications made accessible in the public portal are retained by the authors and/or other copyright owners and it is a condition of accessing publications that users recognise and abide by the legal requirements associated with these rights.

- Users may download and print one copy of any publication from the public portal for the purpose of private study or research.

- You may not further distribute the material or use it for any profit-making activity or commercial gain

- You may freely distribute the URL identifying the publication in the public portal

If you believe that this document breaches copyright please contact us providing details, and we will remove access to the work immediately and investigate your claim. 


\title{
The Mechanism Behind Redox Instability of Anodes in High-Temperature SOFCs
}

\author{
T. Klemensø, ${ }^{\text {a,b,c,z }}$ C. Chung, ${ }^{a}$ P. H. Larsen, ${ }^{a}$ and M. Mogensen ${ }^{\text {a,* }}$ \\ ${ }^{a}$ Ris $\phi$ National Laboratory, Materials Research Department, 4000 Roskilde, Denmark \\ ${ }^{b}$ Department of Chemistry, Technical University of Denmark, 2800 Kgs. Lyngby, Denmark \\ ${ }^{c}$ Topsoe Fuel Cell A/S, 2800 Kgs. Lyngby, Denmark
}

Bulk expansion of the anode upon oxidation is considered to be responsible for the lack of redox stability in high-temperature solid oxide fuel cells (SOFCs). The bulk expansion of nickel-yttria stabilized zirconia (YSZ) anode materials was measured by dilatometry as a function of sample geometry, ceramic component, temperature, and temperature cycling. The strength of the ceramic network and the degree of Ni redistribution appeared to be key parameters of the redox behavior. A model of the redox mechanism in nickel-YSZ anodes was developed based on the dilatometry data and macro- and microstructural observations. (C) 2005 The Electrochemical Society. [DOI: 10.1149/1.2048228] All rights reserved.

Manuscript submitted April 11, 2005; revised manuscript received June 27, 2005. Available electronically September $30,2005$.

Redox stability of the anode in small- and medium-scale solid oxide fuel cells (SOFCs) is considered to be important for commercial and safety reasons. ${ }^{1-3}$ The technological aim has been reported to be 5-20 cycles per year during the lifetime of the cell. ${ }^{1,4}$ The commercial lifetime of $5 \mathrm{yrs}$ thus corresponds to a total of 25-100 cycles.

However, in the state-of-the-art and prevalent Ni-yttria stabilized zirconia (YSZ) anode-supported design, oxidation of the anode is known to be detrimental to the cell performance. ${ }^{1,5,6}$ The degradation upon redox cycling is believed related to bulk expansion of the anode, causing formation of cracks in the electrolyte. For some reason, the anode does not revert to the prereduced volume upon reoxidation but will instead expand. The size of the bulk expansion is known to be dependent on microstructural factors such as particle sizes. ${ }^{1}$ However, the mechanism behind the process has not previously been investigated. ${ }^{1,5,7}$

The purpose of this work was to examine the redox behavior of $\mathrm{Ni}-\mathrm{YSZ}$ cermets with variable porosity and strength by dilatometry and structural investigations and from the observations deduce a model of the redox mechanism occurring in the anodes.

\section{Experimental}

Sample preparation.- Samples with variations in porosity and strength were obtained by applying different ceramic components into the cermets and by using different sample shaping techniques.

Samples were prepared from $\mathrm{NiO}$ powder $(99 \%$ from Alfa Aesar), alumina (Catapal from Sasol), and either 3 or $8 \mathrm{~mol} \% \mathrm{YSZ}$ powder (TZ-3YB or TZ-8Y from Tosoh Co.). The solid material contents in the oxidized and reduced state of the three investigated compositions are shown in Table I. The content of nickel was approximately the same in all three compositions. The ceramic component applied was either calcined $8 \mathrm{~mol} \%$ (8YSZ), calcined 3 mol \% yttria stabilized zirconia (3YSZ), calcined 3YSZ containing $20 \mathrm{wt} \%$ alumina, or uncalcined 3YSZ. The as-delivered raw YSZ powder was calcined as described elsewhere. ${ }^{8,9}$

3YSZ is expected to have improved mechanical properties compared to 8YSZ, also at high temperatures. ${ }^{10,11}$ Addition of alumina to YSZ is reported to increased the strength, ${ }^{10,12}$ and precalcination of the YSZ powder is on empirically grounds believed to improve sintering, thereby potentially improving the strength. ${ }^{8}$

The powders were prepared into slurries, and thin foils were subsequently made using tape-casting technique. Three sample geometries were made from the green tapes. (i) Rolled samples were made from rolling green tape into cylinders. The green rolls were fixed with Pt wire. After sintering the cylindrical samples were approximately $20 \mathrm{~mm}$ in length and $5 \mathrm{~mm}$ in diameter. (ii) Layered

* Electrochemical Society Active Member

${ }^{\mathrm{z}}$ E-mail: trine.klemensoe@ risoe.dk samples were made from stacking pieces of green tape. Each layer was wetted with ethanol to assist adhesion. After sintering, the layered samples were cut down to a size of $18 \times 4 \times 4 \mathrm{~mm}$. (iii) In some of the green tapes, the binder was burned out and the resulting powder was pressed. Pressed bar-shaped samples of dimensions ca. $50 \times 5 \times 5 \mathrm{~mm}$ were made using uniaxial pressing followed by isostatic pressing at $80 \mathrm{MPa}$. After sintering, the bars were cut down into lengths of $20 \mathrm{~mm}$.

The samples were sintered at $1300^{\circ} \mathrm{C}$. Successive reduction and up to four redox cycles were performed during dilatometer measurements at temperatures of 700,850 , and $1000^{\circ} \mathrm{C}$. In addition, a sample was subjected to temperature cycling in-between gas shifts. Table II shows a list of the tested samples. The sample name indicates the ceramic component, sample shape, and test conditions. The ceramic components 8YSZ, 3YSZ, $3 \mathrm{YSZ}+20 \mathrm{wt} \% \mathrm{Al}_{2} \mathrm{O}_{3}$, and uncalcined $3 \mathrm{YSZ}$ are in the sample names abbreviated to, respectively, 8Y, 3Y, 3YA, and Raw3Y. Tests with identical sample composition, shape, and test conditions are differentiated by the added serial letter in the last part of the sample name.

\section{Experimental Procedure}

Measurements were performed with a Netzsch Dil 402E dilatometer and a Setaram DHT 2050 differential dilatometer. In the Netzsch instrument the samples were loaded horizontally and fixed with a spring load. Baselines were achieved using polycrystalline alpha-alumina. In the Setaram instrument, the samples were loaded vertically, and baselines were measured simultaneously using alphaalumina. The data for the two instruments are considered to be consistent when baseline correction is performed. For both instruments, the uncertainty is stated to be $1 \mu \mathrm{m}$, corresponding to an uncertainty of $0.01 \%$ on the relative expansions of the ca. $20-\mathrm{mm}$-long samples.

The samples were heated to 700,850 , or $1000^{\circ} \mathrm{C}$ at $2^{\circ} \mathrm{C} / \mathrm{min}$ in air and allowed to equilibrate. For redox cycling, $9 \% \mathrm{H}_{2} / \mathrm{N}_{2}$ was

Table I. Composition of the investigated materials.

\begin{tabular}{ccrrrr} 
& & \multicolumn{2}{c}{ Oxidized state } & \multicolumn{2}{c}{ Reduced state } \\
\cline { 3 - 6 } Material & Components & $($ wt \%) & $($ vol \%) & (wt \%) & (vol \%) \\
\hline \multirow{2}{*}{$\mathrm{I}$} & $\mathrm{NiO} / \mathrm{Ni}$ & 56.8 & 54.4 & 51.0 & 41.3 \\
& $8 \mathrm{YSZ}$ & 43.2 & 45.6 & 48.9 & 58.8 \\
& $\mathrm{Sum}$ & 100.0 & 100.0 & 99.9 & 100.1 \\
$\mathrm{II}$ & $\mathrm{NiO} / \mathrm{Ni}$ & 55.7 & 52.9 & 49.7 & 43.2 \\
& $3 \mathrm{YSZ}$ & 43.7 & 46.1 & 49.6 & 55.7 \\
& $\mathrm{Al}_{2} \mathrm{O}_{3}$ & 0.6 & 1.0 & 0.7 & 1.1 \\
& $\mathrm{Sum}$ & 100.0 & 100.0 & 100.0 & 100.0 \\
$\mathrm{III}$ & $\mathrm{NiO} / \mathrm{Ni}$ & 56.0 & 50.9 & 50.0 & 41.2 \\
& $3 \mathrm{YSZ}$ & 35.2 & 35.5 & 40.0 & 42.6 \\
& $\mathrm{Al}_{2} \mathrm{O}_{3}$ & 8.8 & 13.5 & 10.0 & 16.2 \\
& $\mathrm{Sum}$ & 100.0 & 99.9 & 100.0 & 100.0
\end{tabular}




\begin{tabular}{|c|c|c|c|c|}
\hline Sample name & Ceramic component & Shape & $\begin{array}{l}\text { Temperature of } \\
\text { redox cycling }\end{array}$ & Thermal treatment \\
\hline 8Y-bar-1000-a & 8YSZ & Bar & $1000^{\circ} \mathrm{C}$ & Isothermal \\
\hline 8Y-bar-1000-b & 8YSZ & Bar & $1000^{\circ} \mathrm{C}$ & Isothermal \\
\hline 8Y-bar-1000-c & $8 \mathrm{YSZ}$ & Bar & $1000^{\circ} \mathrm{C}$ & Isothermal \\
\hline 3Y-bar-1000 & 3YSZ & Bar & $1000^{\circ} \mathrm{C}$ & Isothermal \\
\hline 8Y-roll-1000 & 8YSZ & Roll & $1000^{\circ} \mathrm{C}$ & Isothermal \\
\hline 8Y-roll-700 & $8 \mathrm{YSZ}$ & Roll & $700^{\circ} \mathrm{C}$ & Isothermal \\
\hline 8Y-bar-1000-TC & $8 Y S Z$ & Bar & $1000^{\circ} \mathrm{C}$ & $\begin{array}{l}1000^{\circ} \mathrm{C}-100^{\circ} \mathrm{C} \\
\text { in between gas shifts }\end{array}$ \\
\hline 3Y-roll-850 & 3YSZ & Roll & $850^{\circ} \mathrm{C}$ & Isothermal \\
\hline Raw3Y-roll-850 & Raw 3YSZ & Roll & $850^{\circ} \mathrm{C}$ & Isothermal \\
\hline 3Y-layer-850 & 3YSZ & Layered & $850^{\circ} \mathrm{C}$ & Isothermal \\
\hline 3YA-layer-850 & $3 \mathrm{YSZ}+20 \mathrm{wt} \% \mathrm{Al}_{2} \mathrm{O}_{3}$ & Layered & $850^{\circ} \mathrm{C}$ & Isothermal \\
\hline
\end{tabular}

used as the reducing gas and air as the oxidizing medium. The sample chamber was flushed with $\mathrm{N}_{2}$ in-between atmosphere changes. Temperature cycling from 1000 to $100^{\circ} \mathrm{C}$ and back to $1000^{\circ} \mathrm{C}$ was performed with heating/cooling rates of $2^{\circ} \mathrm{C} / \mathrm{min}$.

The microstructure of the samples was investigated by scanning electron microscopy (SEM). A Fei Quanta 600 equipped with an EDAX thin window detector and EDAX Genesis software was used.

\section{Results}

Dilatometry.-Measured dilatometry profiles of two of the samples (8Y-bar-1000-a and 3Y-bar-1000) are illustrated in Fig. 1. Periods of oxidizing and reducing atmospheres are marked Air and $\mathrm{H}_{2}$, respectively. The flushes with $\mathrm{N}_{2}$ in-between atmosphere changes were short $(15 \mathrm{~min})$ and are not indicated in Fig. 1. When flushing times were as short as this, no changes in sample length were observed during flushing.

The two samples are seen to expand similarly upon heating and to stabilize when the end temperature $\left(1000^{\circ} \mathrm{C}\right)$ is attained. During the first period with reducing atmosphere, no change in length was recorded. This was a common feature observed in most of the samples. Successive oxidizing atmospheres were accompanied by relatively rapid expansions, and upon subsequent reductions shrinkage was seen. Complete reduction or oxidation was observed to occur within 2 and $3 \mathrm{~h}$ of exposure to reducing/oxidizing atmo-

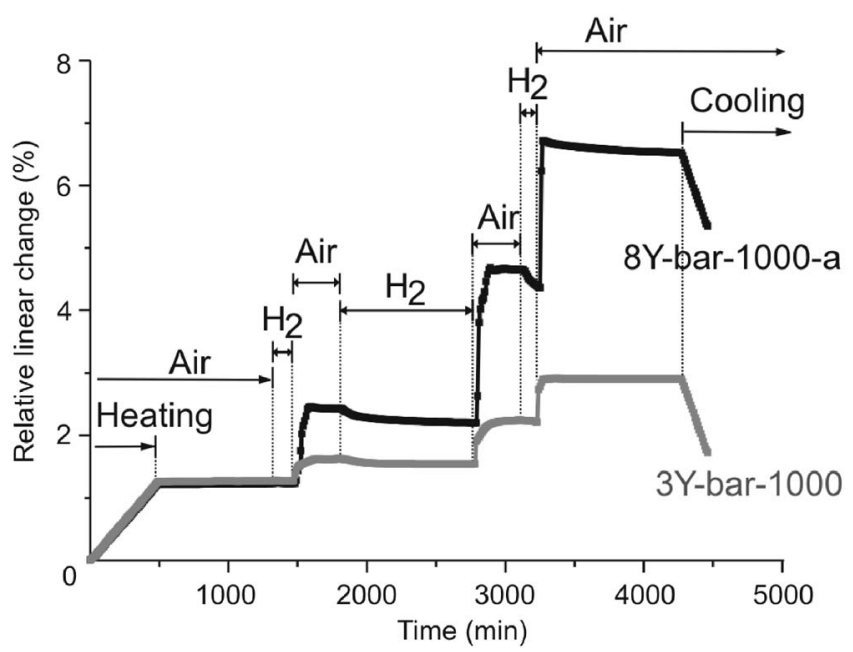

Figure 1. Dilatometry profile of the samples 8Y-bar-1000-a (black curve) and 3Y-bar-1000 (gray curve) during changing reducing atmosphere (marked $\mathrm{H}_{2}$ ) and oxidizing atmosphere (marked Air). sphere, respectively. However, in some cases during later reduction steps, stabilization was not obtained after $2 \mathrm{~h}$ in reducing atmosphere (not clearly seen in Fig. 1). Samples displaying this behavior were characterized by severe macrocracking. In such cases, the shrinkage values obtained after $2 \mathrm{~h}$ of reduction were used for data comparison. As an exception, the alumina-rich sample displayed shrinkage even during the first reduction, and full stabilization was not achieved after up to $48 \mathrm{~h}$ of exposure to reducing atmosphere. In this case, both shrinkage after $2 \mathrm{~h}$ reduction and the maximum measured shrinkage values are reported.

Reproducibility.- To investigate the variation of identically prepared samples, three samples of the type 8Y-bar-1000 were tested under identical conditions. The measured relative linear changes associated with each redox step for the samples 8Y-bar-1000-a, 8Ybar-1000-b, and 8Y-bar-1000-c are listed in Table III.

None or insignificant shrinkage was observed upon the first reduction. The first reoxidation was associated with expansions in the range of $1.2 \%$ in all cases. The data differed by less than $5 \%$. However, during the second cycle, the relative expansion upon reoxidation differed by a factor of two between 8Y-bar-1000-a and 8Y-bar1000-c.

Variable shape.-Three different sample geometries were tested. The measured dimensional changes associated with each redox step and the accumulated linear changes are listed in Table IV Samples containing $3 \mathrm{YSZ}$ as the ceramic component (i.e., 3Y-roll850 and 3 Y-layer-850) were tested at $850^{\circ} \mathrm{C}$ and can be compared. Samples containing 8YSZ (i.e., 8Y-roll-1000 and 8Y-bar-1000-a) were tested at $1000^{\circ} \mathrm{C}$ and are comparable.

For both test compositions and temperatures, higher dimensional changes were observed for the rolled sample compared to the layered and the bar-shaped sample, respectively. The trend was particu-

Table III. Relative linear changes of identical prepared and tested samples (8Y-bar-1000-a, 8Y-bar-1000-b, 8Y-bar-1000-c) upon successive redox steps. Data on the sample 8Y-bar-1000-TC subjected to combined temperature and redox cycling is included. Uncertainty on the data is $\pm 0.01 \%$. Absence of measurement is marked with (一).

\begin{tabular}{lrcrr} 
& $\begin{array}{c}8 \text { Y-bar- } \\
\text { Redox step }\end{array}$ & $\begin{array}{c}8 \text { Y-bar- } \\
1000-\mathrm{a}\end{array}$ & $\begin{array}{c}8 \text { Y-bar- } \\
1000-\mathrm{b}\end{array}$ & $\begin{array}{c}8 \text { Y-bar- } \\
1000-\mathrm{TC}\end{array}$ \\
\hline 1st Red $(\%)$ & 0.00 & -0.10 & -0.07 & -0.01 \\
1st Ox $(\%)$ & 1.19 & 1.21 & 1.25 & 3.09 \\
2nd Red $(\%)$ & -0.22 & -0.10 & -0.10 & -0.17 \\
2nd Ox (\%) & 2.44 & - & 1.21 & 5.55 \\
Sum (\%) & 3.41 & 1.01 & 2.29 & 8.46
\end{tabular}




\begin{tabular}{|c|c|c|c|c|}
\hline Redox step & 3Y-roll-850 & 3Y-layer-850 & 8 Y-roll-1000 & $8 Y-b a r-1000-a$ \\
\hline 1st Red $(\%)$ & 0.00 & 0.00 & 0.00 & 0.00 \\
\hline 1st Ox $(\%)$ & 0.90 & 0.46 & 4.95 & 1.19 \\
\hline 2nd Red $(\%)$ & -0.23 & -0.18 & -0.78 & -0.22 \\
\hline 2nd Ox $(\%)$ & 1.43 & 1.17 & 6.46 & 2.44 \\
\hline 3rd Red (\%) & -0.26 & $-^{\mathrm{b}}$ & $-0.96^{\mathrm{a}}$ & $-0.24^{\mathrm{a}}$ \\
\hline $3 \mathrm{rd} \mathrm{Ox}(\%)$ & 1.96 & - & 2.14 & 2.13 \\
\hline Sum $(\%)$ & 3.80 & 1.45 & 11.81 & 5.30 \\
\hline \multicolumn{5}{|c|}{$\begin{array}{l}\text { a Shrinkage values after } 2 \mathrm{~h} \text { reduction where stabilization was not } \\
\text { achieved. }\end{array}$} \\
\hline
\end{tabular}

larly obvious during the first two cycles and more pronounced in the high-temperature, 8Y-data, where a roll- and a bar-shaped sample were compared.

Enhanced dimensional changes were observed during the second cycle in all samples. For layered and bar-shaped samples, the expansion doubled upon the second oxidation. Upon the third oxidation, further increase in expansion was seen in the sample 3Y-roll-850, whereas the materials containing 8YSZ as ceramic component showed reduced expansion.

Variable ceramic component.- The effect of yttria content, alumina addition, and calcination of the ceramic powder, also believed to reflect the effect of ceramic strength, was studied. The dimensional change of the sample associated with each redox step and the accumulated change is listed in Table V. The alumina-rich sample (3YA-layer-850) was exceptionally slow to stabilize upon reduction. Shrinkage values after the traditional $2 \mathrm{~h}$ of reduction, as well the maximum measured shrinkage (recorded after up to $48 \mathrm{~h}$ exposure to reducing atmosphere) is shown in this case.

As shape and temperature of the experiments vary, the data are only directly comparable two by two. No dimensional changes were generally observed during the first reducing period, except for the alumina-rich sample (3YA-layer-850) where a maximum of up to $0.40 \%$ shrinkage was measured.

Upon the first oxidation, expansion occurred in all samples. However, lower expansions were recorded for $3 \mathrm{Y}$ samples than $8 \mathrm{Y}$ samples (compare 3Y-bar-1000 and 8Y-bar-1000-a), and for samples with calcined powder than those with raw powder (compare 3Y-roll850 and Raw3Y-roll-850).

Addition of $20 \mathrm{wt} \%$ alumina to the ceramic phase appeared to enhance the expansion, that was almost doubled compared to the equivalent sample without alumina (compare 3YA-layer-850 and 3 Y-layer-850). If, however, the shrinkage during the preceding re- duction is taken into account, the effect of the first cycle for the alumina-rich sample is $0.44 \%(=0.84-0.40 \%)$. This net effect (i.e., $n$th expansion $-n$th maximum shrinkage) is similar to the sample without alumina, with a net effect of the first cycle of $0.46 \%$.

In agreement with the observation in the previous section, expansion was greater for the rolled sample (3Y-roll-850) than for the layered and bar-shaped samples of the same composition (3Y-layer850 and 3Y-bar-1000).

Shrinkage occurred in all samples during the second reduction. Shrinkage of the alumina-rich sample during the second reduction was in the same order as during the first reduction and was ca. twice the magnitude of that of other samples.

With the alumina-rich sample as an exception, the trends from the first oxidation were continued upon the second oxidation with enhanced effect. The relative expansions upon the second oxidation have increased, and as before, lower expansions were measured on bars with $3 \mathrm{Y}$ than $8 \mathrm{Y}$, and on samples prepared from calcined powders.

Unlike the other samples, the alumina-rich sample displayed slightly reduced expansion upon the second oxidation. When considering the net effect of the second cycle, much less change was observed for the alumina-rich sample $(0.80-0.42 \%=0.38 \%)$ as opposed to the corresponding sample without alumina $(1.17-0.18 \%$ $=0.99 \%$ ).

Bar-shaped samples were subjected to a third cycle. During the third reduction, significant shrinkage was only observed in 8Y-bar1000-a. Upon the third reoxidation, the expansion of 8Y-bar-1000-a is reduced, and the 3 Y-bar-1000 is in the same range as during the second oxidation.

Temperature.- Two identical prepared samples of the type $8 \mathrm{Y}$ roll were subjected to redox cycling at 1000 and $700{ }^{\circ} \mathrm{C}$, respectively. The relative linear changes observed upon each redox step are compared in Table VI. If the preparation method is assumed to result in a variation of the expansions of less than $50 \%$, the expansion was significantly worse at the higher temperature.

Temperature cycling. - The effect of temperature cycling was investigated by subjecting a sample to $1000-100^{\circ} \mathrm{C}$ temperature cycles in-between atmosphere changes. The dilatometer and temperature profile of the sample 8Y-bar-1000-TC is shown in Fig. 2. Upon the reoxidation, stabilization did not appear to be achieved before the temperature cycle was finished. During reheating an enhanced expansion was seen that ended after $1000^{\circ} \mathrm{C}$ was reached again.

The linear dimensional changes upon the single redox steps for the temperature-cycled sample 8Y-bar-1000-TC are listed in Table III. In the table, the sample is compared to similar but not temperature-cycled samples. The sample 8 Y-bar-1000-a is a twin to 8Y-bar-1000-TC, i.e., originating from the same pressed sample. When compared, temperature cycling seems to have a detrimental

\begin{tabular}{|c|c|c|c|c|c|c|c|}
\hline Redox step & $8 Y-b a r-1000-a$ & 3 Y-bar- 1000 & 3Y-roll-850 & raw3Y-roll-850 & 3 Y-layer-850 & \multicolumn{2}{|c|}{ 3YA-layer-850 } \\
\hline 1st Red (\%) & 0.00 & 0.00 & 0.00 & 0.00 & 0.00 & $-0.08^{\mathrm{a}}$ & -0.40 \\
\hline 1st Ox (\%) & 1.19 & 0.35 & 0.90 & 1.22 & 0.46 & 0.84 & 0.84 \\
\hline 2nd Red (\%) & -0.22 & -0.08 & -0.23 & -0.23 & -0.18 & $-0.08^{\mathrm{a}}$ & -0.42 \\
\hline 2nd Ox (\%) & 2.44 & 0.70 & 1.43 & 1.83 & 1.17 & 0.80 & 0.80 \\
\hline 3rd Red (\%) & $-0.24^{\mathrm{a}}$ & -0.01 & -0.26 & $-^{b}$ & - & - & - \\
\hline 3rd Ox $(\%)$ & 2.13 & 0.67 & 1.96 & - & - & - & - \\
\hline 4th $\operatorname{Red}(\%)$ & - & - & -0.53 & - & - & - & - \\
\hline 4th Ox $(\%)$ & - & - & 1.81 & - & - & - & - \\
\hline Sum $(\%)$ & 5.30 & 1.63 & 5.08 & 2.82 & 1.45 & 1.48 & 0.82 \\
\hline
\end{tabular}

${ }^{a}$ Shrinkage values after $2 \mathrm{~h}$ reduction where stabilization was not achieved. For the sample 3 YA-layer- 850 a second subcolumn is shown. In the subcolumn to the right, the values of the maximum measured shrinkage (after $28-48 \mathrm{~h}$ of reduction) are used.

b Absence of measurements. 


\begin{tabular}{|c|c|c|}
\hline Redox step & 8Y-roll-1000 & 8 Y-roll-700 \\
\hline 1 st $\operatorname{Red}(\%)$ & 0.00 & -0.01 \\
\hline 1 st Ox (\%) & 4.95 & 0.99 \\
\hline 2nd Red (\%) & -0.78 & -0.19 \\
\hline 2nd Ox (\%) & 6.46 & $-^{\mathrm{a}}$ \\
\hline Sum $(\%)$ & 10.63 & 0.79 \\
\hline
\end{tabular}

effect on the dimensional changes associated with oxidations. The expansions of the temperature-cycled sample are more than a factor of two higher.

The calculated thermal expansion coefficients (TECs) of the different states are listed in Table VII together with data from literature. When possible, the average of the heating and cooling ramp was applied for calculations. Considering the absolute TEC values, reductions seemed to have only minor effect on the TEC. However, when the oxidized states were compared (i.e., sintered compared with second oxidized state) and the reduced states compared (i.e., first reduced compared with second reduced), the TEC appeared to increase upon redox cycling.

Macro- and microstructural observations.- From SEM images it was qualitatively verified that the applied shaping techniques resulted in different as-sintered porosities. SEM images of a barshaped, a layered, and a rolled sample are shown in Fig. 3. Bars were observed to be less porous than the layered samples, and the layered samples were less porous than the rolls, despite the origin from the same green tape cast material. The roll-shaped samples appeared to be damaged during preparation. Relatively big microcracks were seen associated with the surface under tension upon rolling (cf. Fig. 3c), accounting for the increased porosity.

The porosity $(\varepsilon)$ of the samples was quantified by weighing and geometric gauging, Archimedes' method, or mercury porosimetry. The measurements are listed in Table VIII. The microscopic visible lower porosity of the as-sintered bars was confirmed; however, rolls generally did not display higher porosity than layers. For porosity data on the rolls, only mercury porosimetry was applied. The method is known to be more appropriate for detection of small to intermediate-sized pores. Porosities above ca. $100 \mu \mathrm{m}$ are difficult

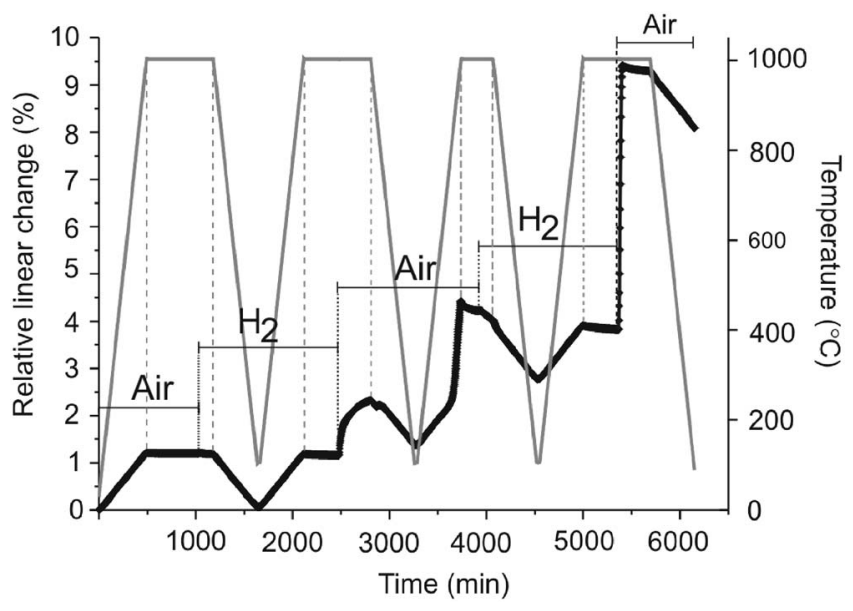

Figure 2. Dilatometry profile (black curve) of the sample 8Y-bar-1000-TC during combined temperature cycles (gray curve) and changing atmospheres (reducing periods marked $\mathrm{H}_{2}$ and oxidizing marked Air).

\begin{tabular}{|c|c|c|c|}
\hline Material & State & $\begin{array}{l}\text { Temperature range } \\
\left({ }^{\circ} \mathrm{C}\right)\end{array}$ & $\begin{array}{c}\text { TEC } \\
\left(10^{-6} \mathrm{~K}^{-1}\right)\end{array}$ \\
\hline 8Y-bar & Sintered & $30-1000$ & 12.4 \\
\hline 8Y-bar & 2nd Oxidized & $100-1000$ & 13.2 \\
\hline 8Y-bar & 1st Reduced & $100-1000$ & 12.5 \\
\hline 8Y-bar & 2nd Reduced & $100-1000$ & 13.3 \\
\hline $8 Y S Z$ & & $50-1000$ & 10.3 \\
\hline $\mathrm{NiO}$ & & $50-1000$ & 14.1 \\
\hline $\mathrm{Ni}$ & & $50-1000$ & 16.9 \\
\hline
\end{tabular}

to detect, as, for instance, the defects introduced upon rolling. Thus, the similarity in measured porosity between rolled and layered samples is ascribed to the test method.

Redox cycles were observed to give rise to macroscopic visible cracks. Figure 4 illustrates samples subjected to three redox cycles. The macrocracks observed in 3Y-bar-1000 were few and shallow (cf. Fig. 4a). In contrast, severe cracking was seen in the 8Y-bars and rolled samples (cf. Fig. $4 \mathrm{~b}$ and c), and delamination was seen in the layered samples (cf. Fig. 4d).

The microstructural effects of redox cycling were investigated with scanning electron microscopy (SEM). As example, images of a sample of the type 8Y-bar-1000 in the as-sintered and redox cycled states are shown in Fig. 5. In the images, YSZ appears as the lighter phase, $\mathrm{NiO}$ as the darker phase, and pores appear as black. Increased porosity with the number of redox cycles was generally observed. The increase in porosity was possible to quantify by porosity measurements (cf. Table VIII). From the pictures, it was also evident that the YSZ phase appeared less coherent upon redox cycling. Actual microcracks were rarely seen, although a few could be identified and are indicated by arrows in Fig. 5c. Open and wide failures were seen to be predominant in the reoxidized state.

The phases present in the alumina-rich sample (3YA-layer) were investigated by X-ray diffraction (XRD). In the sintered state, traces of the spinel phase $\left(\mathrm{NiAl}_{2} \mathrm{O}_{4}\right)$ were evident, as reported in the literature. ${ }^{14} \mathrm{SEM}$ investigations also indicated the presence of a fine-grained $\mathrm{Ni}-\mathrm{Al}$ phase (not shown here) in the samples. Upon
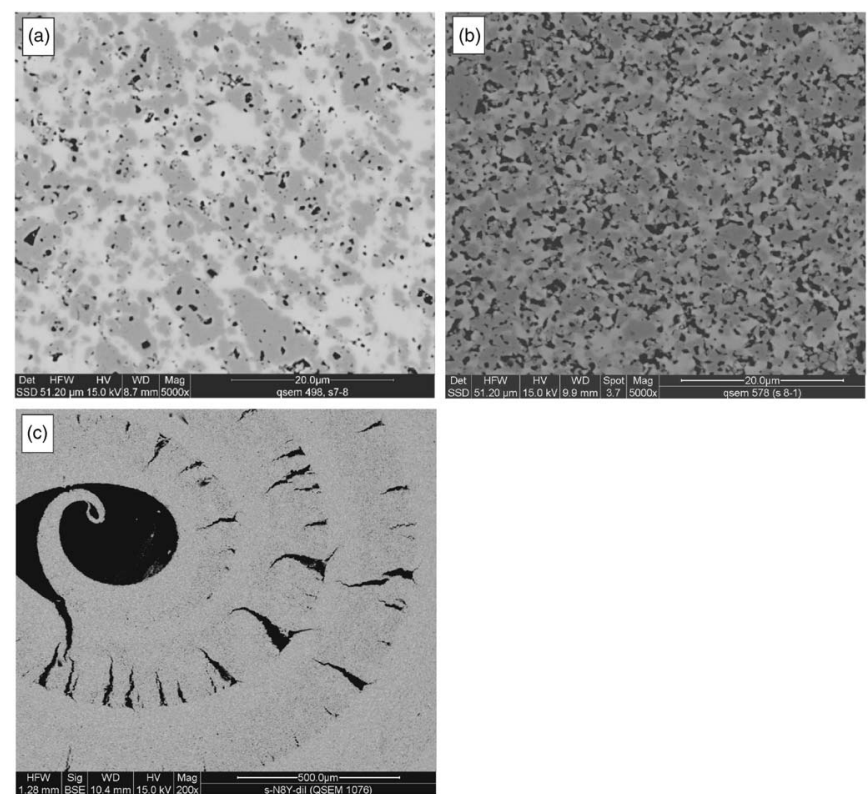

Figure 3. SEM images of sintered samples: (a) 3Y-bar, (b) 3Y-layer, and (c) 8Y-roll. 


\begin{tabular}{|c|c|c|c|c|c|c|c|c|}
\hline State & Method & 8Y-bar & 8Y-layer & 3Y-bar & 3Y-layer & 3Y-roll & 3YA-layer & 3YA-roll \\
\hline \multirow[t]{3}{*}{ Sintered } & $\varepsilon_{\text {geom }}(\%)$ & 1.5 & 12.3 & 7.5 & 17.0 & $-{ }^{\mathrm{a}}$ & - & - \\
\hline & $\varepsilon_{\text {Arch }}(\%)$ & 0.5 & 4.4 & 5.9 & 14.9 & - & - & - \\
\hline & $\varepsilon_{\mathrm{Hg}}(\%)$ & - & - & - & 17.1 & 15.0 & 13.7 & 17.9 \\
\hline \multirow[t]{3}{*}{ Reduced } & $\varepsilon_{\text {geom }}(\%)$ & 23.8 & 28.3 & 27.8 & 35.5 & - & - & - \\
\hline & $\varepsilon_{\text {Arch }}(\%)$ & 17.1 & 27.3 & 25.6 & 33.0 & - & - & - \\
\hline & $\varepsilon_{\mathrm{Hg}}(\%)$ & - & - & - & - & - & - & - \\
\hline \multirow[t]{3}{*}{ Reoxidized } & $\varepsilon_{\text {geom }}(\%)$ & 12.7 & - & 18.0 & 28.6 & - & - & - \\
\hline & $\varepsilon_{\text {Arch }}(\%)$ & 3.7 & 19.9 & 11.8 & 12.4 & - & - & - \\
\hline & $\varepsilon_{\mathrm{Hg}}(\%)$ & - & 10.1 & - & - & - & - & - \\
\hline
\end{tabular}

reduction of the sample, it was not possible to detect any alumina phases by XRD; however, from thermodynamics it is believed that the spinel will reduce into $\mathrm{Ni}$ and $\mathrm{Al}_{2} \mathrm{O}_{3}$.

The apparent disappearance of $\mathrm{Al}$ phases in the diffractogram upon reduction may be explained by the lower atomic number of aluminum compared to nickel and zirconium, and small grain sizes, as the strongest peak from the observed Al-containing phase was only $5 \%$ compared to the strongest peak of the other phases.

\section{Discussion}

Based on the experimental observations, a model illustrating the redox processes has been developed. The model is shown in Fig. 6. The processes are illustrated for the $2 \mathrm{D}$ structure consisting of unisized particles shown in Fig. 6a. Figure 6a represents the as-sintered structure. In the figure, the YSZ particles are indicated by a hatched pattern, and the $\mathrm{NiO}$ particles indicated by a plain, pale gray color. In accordance with the SEM images of the sintered structures (cf. Fig. 3), the model cermet in the sintered state is relatively dense and consists of percolating networks of YSZ and NiO.

Upon reduction, the phase change of $\mathrm{NiO}$ to $\mathrm{Ni}$ occurs and implies a $25 \%$ volume reduction of the nickel phase. ${ }^{15}$ Thus, reduction is bound to introduce decreased nickel-particle sizes and reorganization of the phase. The changes in the nickel phase are illustrated in Fig. 6b. However, the YSZ phase is believed unaffected by the first reduction process, as illustrated by an unchanged YSZ-particle network in Fig. 6b. From this, the lack of dimensional change generally observed upon the first reduction (cf. Tables III-VI), is explained by the stable YSZ network. From the porosity data of the reduced
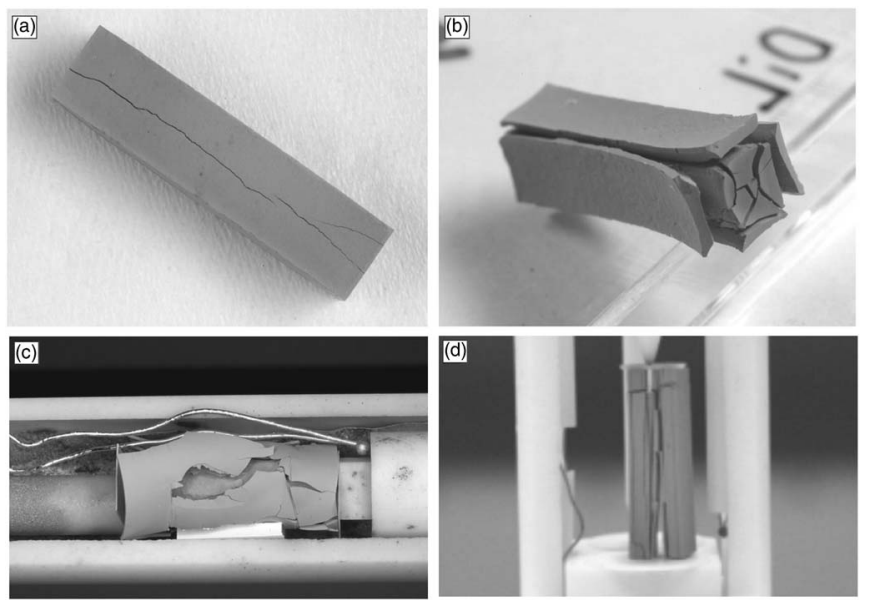

Figure 4. Samples subjected to three redox cycles: (a) 3Y-bar-1000, (b) 8Y-bar-1000, (c) 8Y-roll-1000, and (d) 3Y-layer-850. samples (cf. Table VIII) it is also indicated that the reduction is accommodated by increased porosity within the structure and no marked shrinkage.

As an exception, a considerable shrinkage was observed in the alumina-rich sample (3YA-layer-850) upon the first reduction (cf. Table V). The exceptional case may be explained by the presence of the spinel phase $\left(\mathrm{NiAl}_{2} \mathrm{O}_{4}\right)$ in the as-sintered state. If all the alumina is assumed to react as seen by Kesler and Landingham, ${ }^{14} 13 \mathrm{wt} \%$ of the $\mathrm{NiO}$ will be in the form of spinel. If the spinel phase in the sintered state of the structure is a part of the ceramic network, decomposition of the oxide structure during reduction can explain the observed shrinkages. The much slower stabilization time observed for reductions of the alumina-rich sample may reflect slow kinetics.

Reorganization of the Ni network continues after the initial reduction due to sintering. ${ }^{16-24}$ Sintering is known to intensify with increased porosity and temperature. In Fig. $6 \mathrm{c}, \mathrm{Ni}$ sintering is illustrated by increased particle sizes and coalesced grains.

When reoxidized, the nickel phase expands back to the assintered volume (corresponding to a phase volume expansion of $33 \%$ ). However, the structural changes while in the reduced state results in a different oxidized volume structure. The changed $\mathrm{NiO}$ network is believed to induce local tensile stresses in the YSZ net-
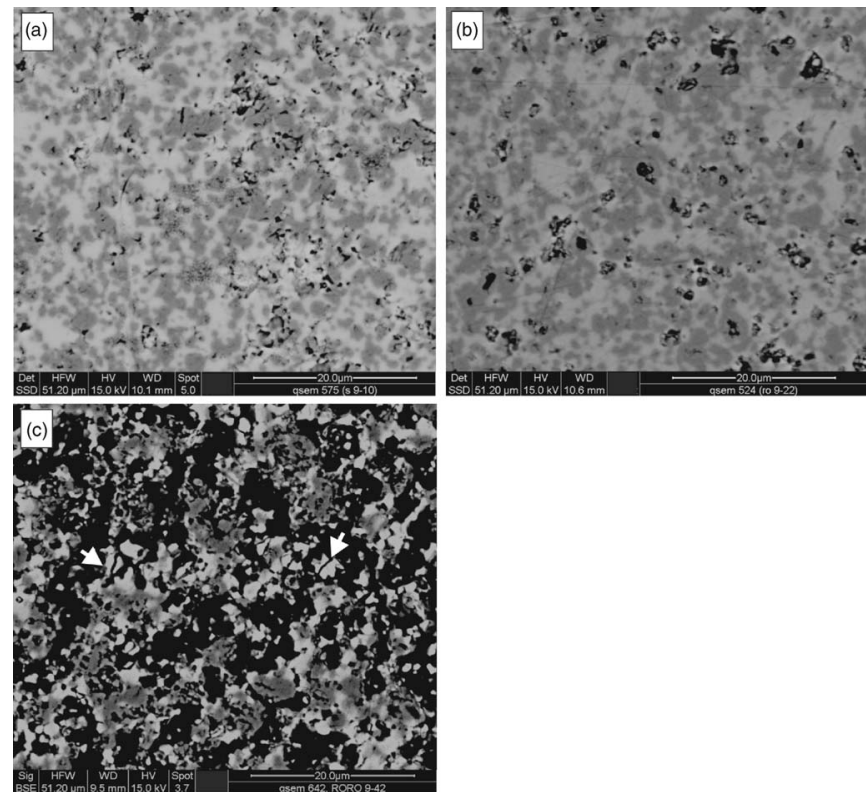

Figure 5. SEM images of sintered and redox cycled sample of the type 8Y-bar-1000: (a) sintered, (b) after the first redox cycle, and (c) after the fourth redox cycle. The arrows point to microcracks. 


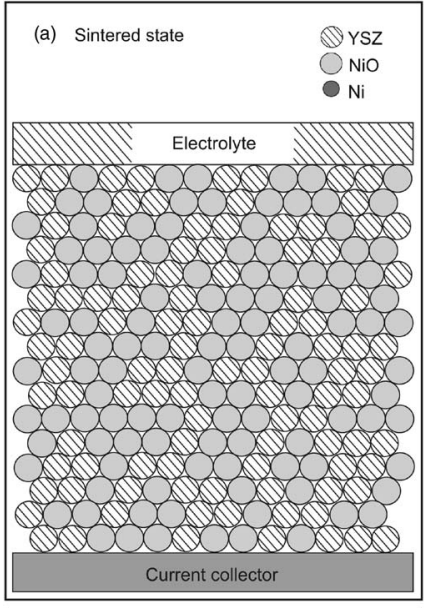

(b) Immediate reduced state
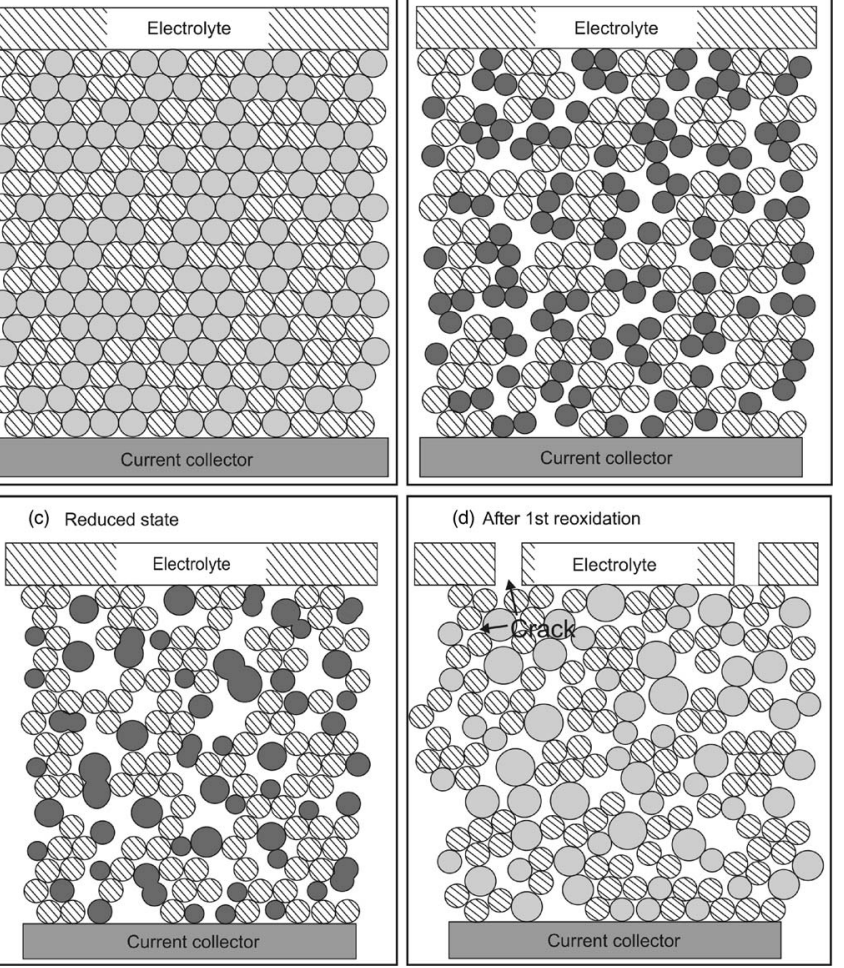

Figure 6. Model illustrating the redox mechanism in Ni/YSZ cermets. The cartoon illustrates (a) the sintered state, (b) the short-term reduced state, (c) the long-term reduced state, and (d) the reoxidized state. The arrows in (d) point to a crack in the electrolyte and a failure in the ceramic network of the cermet, respectively.

work that in some places causes failure. The local failures in the network then allows for the observed bulk expansion and increased porosity. This again gives rise to cracks in the electrolyte. The processes are illustrated in Fig. 6d.

The model implies that the damage depends on the ceramic network strength and the degree of $\mathrm{Ni}$ redistribution. Lower bulk expansions upon the first reoxidation were indeed observed for cermets with improved mechanical properties due to the yttria content or precalcination of the powder (compare 8Y-bar-1000-a and 3Ybar-1000 in Table V). Lower bulk expansions upon the firstst reoxidation were also seen for samples with lower porosity (compare Table IV and Fig. 3) and were suggested for samples tested at lower temperature (cf. Table VI).

However, from the reproducibility study on the sample type $8 \mathrm{Y}-$ bar-1000 (cf. Table III), the dilatometer measurements were seen to be sensitive to minor variations in microstructure. For identically prepared bar-shaped samples, a minor variation of 5\% upon the first oxidation was seen. During the second oxidation the variation between samples increased to $50 \%$. The variation is believed to reflect the stochastic nature of the Ni-redistribution process and the fracture mechanism. The increase in variation upon the second oxidation may be explained by the increased porosity. From this, higher variations for sample geometries other than bars are predicted. The effect of test temperature (cf. Table VI) and precalcination of the powder (cf. Table V) was based on measurements on rolls. Considering this, the conclusions regarding these are to be taken tentatively. Also, the effect of porosity was based on comparisons with rolls and is tentative (cf. Table IV). In addition, the enhanced porosity of the rolls is believed to influence the strength. The porosity and deformation introduced during the green state shaping is likely to reduce strength, which then becomes a second variable when comparing rolls with other shapes.

If temperature cycling is believed to weaken the ceramic part of the cermet structure, the model predicts enhanced expansion for a temperature-cycled sample upon redox cycling. From the change in the TEC values upon redox cycling (cf. Table VII) it was indicated that the YSZ network was damaged, and the nickel network became increasingly influential due to temperature cycling. In accordance, increased expansions for a temperature-cycled sample was observed (cf. Table III).

Following the redox cycles, the steps in Fig. 6 are repeated. In accordance with observations, reduction now implies shrinkage as the YSZ network is partly disconnected (cf. Table III, VI, and V). The created increased porosity will promote increased Ni reorganization and enhanced bulk expansion. Enhanced dimensional changes upon the second cycle were also observed in most cases (cf. Table III, VI, and V). However, considering an uncertainty from sample preparation above $50 \%$, the tendency is only suggested in few cases.

As the structure becomes increasingly porous and fragmented with the number of redox cycles and $\mathrm{Ni}$ sintering diminishes, the microstructural changes are expected to accommodate within the structure and bulk expansion to decrease. Ignoring the uncertainty from sample preparations, indications of diminished bulk expansion were seen during the third cycle (cf. Table IV). From Table IV it is indicated that the effect first appeared in the high-temperature tested samples (8Y-roll-1000 and 8Y-bar-1000-a) that expanded the most during the first and second cycle. In accordance with the model, it was expected that the effect first occur in the samples with accelerated degradation processes.

The effect of adding alumina to the ceramic phase was ambiguous. Due to formation and dissociation of a nickel alumina spinel, large dimensional changes were associated with the single reduction and reoxidation step (cf. Table V). Thus, the phase change is expected to reduce the strength of the ceramic network. However, when the net effect of the first cycle was considered, the performance of the alumina-rich sample was not worse. From this it appeared that the spinel-related dimensional changes are reversible and do not promote significant weakening of the structure. In addition, indications of the alumina sample performing better upon the secind cycle were seen. Addition of alumina appeared to have a complex impact on the strength.

\section{Conclusion}

The redox behavior of nickel-YSZ anode materials was studied as a function of sample geometry, ceramic component, temperature, and temperature cycling. Based on the experimental results, a model of the redox behavior in SOFC nickel-YSZ anode materials was proposed. Key parameters for achieving redox stable anodes were indicated to be the ceramic network strength and the degree of restriction of Ni-particle relocation and Ni-particle coarsening.

\section{Acknowledgment}

This work has been supported by Topsoe Fuel Cell A/S, the Danish Industrial $\mathrm{PhD}$ programme, and the EFP DK-SOFC b, longterm SOFC R\&D. H. Z. Stummann (Haldor Topsøe A/S) is acknowledged for technical support on the dilatometer. F. W. Poulsen (Risø National Laboratory) is acknowledged for help and discussion of the XRD data. Y. L. Liu (Ris $\varnothing$ National Laboratory) is acknowledged for the SEM analysis of the alumina-rich sample.

Ris $\phi$ National Laboratory assisted in meeting the publication costs of this article.

\section{References}

1. G. Robert, A. Kaiser, and E. Batawi, in 6th European Solid Oxide Fuel Cell Forum Proceedings, M. Mogensen, Editor, p. 193, European Fuel Cell Forum, Oberrohrdorf, Switzerland (2004)

2. G. Robert, A. Kaiser, K. Honegger, and E. Batawi, in 5th European Solid Oxide Fuel Cell Forum Proceedings, J. Huijsmans, Editor, p. 116, European Fuel Cell Forum, Oberrohrdorf, Switzerland (2002). 
3. S. Tao and J. T. S. Irvine, Nat. Mater, 2, 320 (2003).

4. G. Robert, A. F.-J Kaiser, and E. Batawi, U.S. Pat. 2003/0165726 A1 (2003).

5. D. Fouquet, A. C. Müller, A. Weber, and E. Ivers-Tiffée, Ionics, 9(1-2), 103 (2003).

6. M. Cassidy, G. Lindsay, and K. Kendall, J. Power Sources, 61, 189 (1996)

7. G. Stathis, D. Simwonis, F. Tietz, A. Moropoulou, and A. Naoumides, J. Mater. Res., 17, 951 (2002)

8. C. Bagger, in Fuel Cell Seminar, p. 241, Tucson, AZ (1992).

9. S. Primdahl, M. J. Jørgensen, C. Bagger, and B. Kindl, in SOFC-VI, S. C. Singhal and M. Dokiya, Editors, PV 99-19, p. 793, The Electrochemical Society Proceedings Series, Pennington, NJ (1999).

10. R. Stevens, in Engineered Materials Handbook, Ceramic and Glasses, Vol. 4, S. J. Schneider, Editor, p. 775, ASM International, Materials Park, OH (1991).

11. C. C. Appel, N. Bonanos, A. Horsewell, and S. Linderoth, J. Mater. Sci., 36, 4493 (2001).

12. G. A. Carter, R. D. Hart, N. M. Kirby, and D. Milosevic, J. Australas. Ceram. Soc., 39, 149 (2003).

13. M. Mori, T. Yamamoto, H. Itoh, H. Inaba, and H. Tagawa, J. Electrochem. Soc., 145, 1374 (1998).

14. O. Kesler and R. L. Landingham, Mater. Res. Soc. Symp. Proc., 756, 539 (2003).
15. S. Primdahl, Ph.D. Thesis, University of Twente, The Netherlands (1999).

16. R. J. Aaberg, R. Tunold, F. W. Poulsen, and N. Bonanos, in 2nd European Solid Oxide Fuel Cell Forum Proceedings, B. Thorstensen, Editor, p. 363, European Fuel Cell Forum, Oberrohrdorf, Switzerland (1996).

17. R. Ihringer, S. Rambert, and J. Van Herle, in 4th European Solid Oxide Fuel Cell Forum Proceedings, A. J. McEvoy, Editor, p. 241, European Fuel Cell Forum, Oberrohrdorf, Switzerland (2000).

18. L. Kindermann, F. W. Poulsen, and C. Bagger, in 3rd European Solid Oxide Fuel Cell Forum Proceedings, P. Stevens, Editor, p. 133, European Fuel Cell Forum, Oberrohrdorf, Switzerland (1998).

19. L. Grahl-Madsen, P. H. Larsen, N. Bonanos, J. Engell, and S. Linderoth, in 5th European Solid Oxide Fuel Cell Forum Proceedings, J. Huijsmans, Editor, p. 82, European Fuel Cell Forum, Oberrohrdorf, Switzerland (2002).

20. S. P. Jiang, J. Mater. Sci., 38, 3775 (2003).

21. D. Simwonis, F. Tietz, and D. Stöver, Solid State Ionics, 132, 241 (2000).

22. R. Vassen, D. Simwonis, and D. Stöver, J. Mater. Sci., 36, 147 (2001).

23. A. Ioselevich, A. A. Kornyshev, and W. Lehnert, Solid State Ionics, 124, 22 (1999).

24. A. Ioselevich, A. A. Kornyshev, and W. Lehnert, J. Electrochem. Soc., 144, 3010 (1997). 